\title{
Pembentukan Identitas Korporat PT Kompas Media Nusantara sebagai Penyedia Konten (Content Provider) Televisi Lokal Pertama di Indonesia
}

\author{
Olivia Lewi Pramesti \\ Mahasiswa S2 Komunikasi UGM Yogyakarta; \\ Anggota Aliansi Jurnalistik Independen (AJI) Yogyakarta; \\ Kontributor National Geographic Indonesia (NGI) Online Indonesia
}

\begin{abstract}
Communication technology development has affected media industry. This condition forces media industry to adapt in order to keep them in the competition. Media industry now should operate in multi-platform basis. In corporate theme, one challenge that media should answer is building new corporate identity. The steps to build corporate identity are defining problem, planning and organizing the direction, acting and communicating, and program evaluation. This paper is discussing how PT Kompas Media Nusantara build their corporate identity in television industry. The brand Kompas is well-known as a daily newspaper. By 2011, Kompas held their own television stadion named KompasTV. This paper consist of four parts. First is introduction, describes about KompasTV and the media shake-up phenomenon in Indonesia. Second is literature review consists of corporate communication and corporate identity. Third is discussion about how KompasTV build their corporate identity. The fourth part is conclusion.
\end{abstract}

Keywords: corporate identity, corporate communication

\begin{abstract}
Abstrak
Perkembanan teknologi komunikasi telah berdampak pada industri media. Kondisi ini memaksa industri media untuk menyesuaikan diri agar mereka tetap berada dalam lingkaran kompetisi. Industri media kini harus melakukan basis multiplatform. Dalam bahasan tentang korporat, salah satu tantangan yang harus dijawab media adalah membangun identitas korporat. Langkah-langah untuk melakukannya adalah mendefinisikan masalah, perencanaan dan organisasi tujuan, aksi dan komunikasi, serta evaluasi. Tulisan ini mendiskusikan bagaimana PT Kompas Media Nusantara membangun identitas korporatnya di industri televisi. Merek Kompas sendiri telah luas diketahui sebagai surat kabar harian. Tahun 2011, Kompas mendirikan stasiun televisi bernama KompasTV. Artikel ini terdiri dari empat bagian. Bagian pertama menjelaskan mengenai KompasTV dan fenomena kocok ulang bisnis media di Indonesia. Bagian kedua adalah ulasan literatur tentang komunikasi korporat dan identitas korporat. Bagian ketiga membahas bagaimana KompasTV membentuk identitas korporatnya, dan ditutup dengan kesimpulan di bagian akhir.
\end{abstract}

Kata Kunci: identitas korporat, komunikasi korporat 


\section{Pendahuluan: KompasTV dan Fenomena Media Shake-up di Indonesia}

Perkembangan teknologi digital-sebagai bentuk perkembangan teknologi komunikasi-saat ini berdampak pada sebuah industri khususnya industri media. Untuk melakukan adaptasi terhadap perkembangan teknologi digital, maka fenomena media shake-up atau kocok ulang bisnis media pun menjadi tren global saat ini.

Fenomena media shake-up ini sudah terjadi di Amerika Serikat sekitar 12 tahun lalu. Hal ini dapat terlihat dari para pemain media besar dan kecil di Amerika Serikat melakukan formulasi atas bisnis medianya dengan melakukan merger dan akuisisi. Tren ini memang tampak diminati karena membawa banyak keuntungan. Korporasi makin kuat, profit lebih tinggi, jangkauan lebih besar, produktivitas meningkat, serta memiliki dampak efisien yang besar (Ambardi, 2011).

Tak hanya itu saja, fenomena media shake-up juga menjadi potret memudarnya batas-batas tradisional media konvensional baik dari segi bisnis, teknologi, maupun kepemilikan. Kombinasi semua lini bisnis seperti bisnis telepon dan layanan televisi, radio dengan televisi, internet dengan televisi, dan lainnya terintegrasi dalam berbagai platform teknologi digital. Kendati begitu, tren ini akhirnya membawa pergerasan pada kualitas media content atau isi media serta content delivery atau mode distribusi media.

Fenomena media shake-up ini memang tidak bisa dihindari karena pada dasarnya tren struktural media industri di abad 20 meliputi empat aspek yakni pertumbuhan media, integrasi, globalisasi, dan kepemilikan media (Croteau, 2001: 73).

Pesatnya bisnis kocok ulang media memang akhirnya menjadi tren negaranegara dunia karena merupakan langkah strategis menghadapi perkembangan teknologi informasi. Tak bisa dipungkiri bahwa dengan perkembangan teknologi informasi, pelaku bisnis media menjadi terbantu untuk melancarkan misi dan tujuannya. Media shake-up ternyata tak hanya terjadi di negara maju saja melainkan juga terjadi di Indonesia. Bahkan intensitasnya semakin meningkat pada lima tahun terakhir ini. Merger dan akuisisi sudah dan tengah berlangsung di Indonesia. Masing-masing kelompok membangun korporasi lintas sektor yakni bisnis televisi, radio, media cetak, serta portal digital dan internet.

Formulasi dalam media shake-up bisa dalam bentuk merger, akuisisi, atau pengembangan multiplatform oleh sebuah media. Misalnya Kelompok Kompas Gramedia (KKG) yang membangun korporasinya lintas sektor, seperti bisnis televisi lewat $\mathrm{TV}_{7}$ (kemudian berganti nama menjadi Trans7 
setelah berpindah kepemilikan ke kelompok Transcorp), radio lewat Sonora dan Eltira, media cetak lewat Kompas, Persda, dan Majalah, serta internet lewat portalnya kompas.com. Kelompok Media Indonesia memiliki MetroTV, Media Indonesia (cetak), serta metrotvnews.com dan mediaindonesia.com untuk portal internetnya. Hal serupa juga dilakukan korporasi lain seperti Kelompok Mahaka, Kelompok MRA, Kelompok Media Nusantara Citra (MNC), Jawa Pos Media Corporation (JPMC), serta First media.

Contoh terkini adalah Grup Para dengan membeli Detik.com dengan harga sekitar 600 miliar. Atau kelompok KKG yang baru saja mendirikan stasiun televisi KompasTV. Kendati demikian, baik KompasTV maupun Detik.com masih terpisah dari segi pengelolaan dan layanan informsi meskipun dari grup yang sama.

Kehadiran new media menjadi tantangan tersendiri bagi sebuah pelaku bisnis atau perusahaan media . Mereka memang dituntut untuk merancang strategi agar makin kompetitif dalam persaingan. Seperti yang terjadi pada PT Kompas Nusantara, yang pada September 2011 lalu baru saja meluncurkan bisnis televisinya yaitu KompasTV. PT Kompas Media Nusantara saat ini tergabung dalam Kelompok Kompas Gramedia (KKG). Hingga saat ini KKG adalah salah satu kelompok media terbesar di Indonesia dengan bisnis medianya di antaranya koran, majalah, persda, radio, hingga internet. Jumlahnya pun puluhan dan tersebar di seluruh Indonesia.

Kompas merupakan market leader surat kabar harian nasional. Berdasarkan data dari pihak redaksi, tiras penjualan koran cetak yang mencapai lebih dari 500.000 per harinya di mana angka ini merupakan tiras terbesar di antara surat kabar nasional lainnya. Kompas sendiri telah memiliki wahana internet Kompas.com - sebagai portal beritanya. Namun begitu Kompas belum memiliki platform penting yaitu televisi yang berfungsi sebagai content delivery channel. Sebelumnya pernah ada TV7 yang dibeli Kompas, lalu kemudian dibeli TransTV, dan sekarang namanya berubah Trans7. Pada 9 September 2011 ini Kompas meluncurkan penyedia konten atau dikenal dengan KompasTV dengan production house sendiri yang dinamakan KG Production.

Dalam beroperasi, KompasTV menggandeng sekitar 9 televisi lokal di beberapa kota besar di Indonesia untuk sharing program. Menurut Sularto (2011: 274) sebagai penyedia konten, Kompas pun akan memproduksi konten-konten berkualitas internasional. Kehadiran Kompas sebagai penyedia konten di Indonesia adalah fenomena baru dan pertama di Indonesia. Hal ini dikatakan karena era televisi digital di Indonesia baru akan berlangsung pada 2018 mendatang. Saat ini, menurut Ketua Komisi Penyiaran Indonesia Daerah (KPID) Daerah Istimewa Yogyakarta 
(DIY) Rahmat Arifin, Indonesia saat ini baru memasuki era sosialisasi televisi digital.

Belum adanya regulasi mengenai televisi Digital ini menjadi tantangan KompasTV untuk melakukan pengembangan bisnisnya khususnya bisnis televisi. Keberanian KompasTV menyebut dirinya sebagai penyedia konten bagi televisi lokal tentu saja menjadi persoalan menarik untuk dikaji. Di tengah kebijakan digital Indonesia yang belum tuntas, justru KompasTV berinisiatif menggandeng televisi lokal di Indonesia.

Program yang ditawarkan KompasTV adalah program edukatif yang fungsinya mencerdaskan bangsa. Konten program tayangan KompasTV menekankan pada eksplorasi Indonesia baik kekayaan alam, khasanah budaya, Indonesia kini, hingga talenta berprestasi. Bahkan, KompasTV menyediakan pula produksi film layar lebar dengan jalan cerita menarik dan didukung talenta seni berbakat Indonesia. Tak heran KompasTV memiliki tagline "Inspirasi Indonesia".

Sebagai unit perusahaan baru dalam PT Kompas Media Nusantara, tentu saja bukan permasalahan gampang bagi KompasTV untuk membangun image bahkan membentuk sebuah reputasi perusahaan. Lebih lagi usianya baru menginjak empat bulan. Tentu saja KompasTV memiliki strategi komunikasi korporat tersendiri untuk bisa memenangkan brand-nya sebagai televisi Penyedia konten Pertama di Indonesia.

\section{Komunikasi Korporat dan Pembentukan Identitas Perusaaan}

Komunikasi korporat adalah cara yang dilakukan sebuah perusahaan untuk mengkomunikasikan sesuatu kepada konstituen. Komunikasi ini menyangkut organisasi baik secara internal maupun eksternal. Konstituen adalah sesuatu institusi yang menentukan mati tidaknya perusahaan. Konstituen ini meliputi stakeholder, karyawan, pelanggan (customer), pemerintah, media, dan lainnya.

Komunikasi

korporat

berhubungan dengan bagaimana perusahaan membangun reputasi perusahaan. Reputasi perusahaan menurut Argenti (2010: 95) adalah untuk membentuk sebuah identitas unik dan memproyeksikan satu set citra yang koheren dan konsisten kepada publik. Reputasi perusahaan ini meliputi kredibilitas di mata investor (credibility), terpercaya dalam pandangan konsumen (trusworthiness), keterandalan di mata konsumen (reliability), dan tanggungjawab sosial (responsibility) (Ardianto,2010).

Untuk membentuk reputasi perusahaan, perusahaan menggunakan strategi korporat. Strategi dalam korporat menurut Cutlip (2005: 292) dapat didefinisikan sebagai penentuan tujuan 
Olivia Lewi Pramesti, Pembentukan Identitas Korporat PT Kompas Media Nusantara sebagai Penyedia Konten (Content Provider) Televisi Lokal Pertama di Indonesia

dan sasaran dasar jangka panjang suatu perusahaan, pengambilan rangkaian tindakan, dan pengalokasian sumber daya yang perlu untuk melaksanakan cita-cita.

Strategi korporat dilakukan dengan membentuk corporate identity atau identitas perusahaan. Identitas perusahaan menampilkan jati diri perusahaan. Identitas memengaruhi corporate image atau kesan organisasi dari sudut pandang konstituennya. Sementara itu ada tiga tahap pembentukan identitas perusahaan yakni visual (berhubungan dengan logo, gambar, moto, dan lain-lain), komunikasi (bagaimana visual ini dikomunikasikan), dan behaviour.

Identitas Perusahaan

(nama, merk, moto, simbol, presentasi diri)

$\downarrow \quad \uparrow \quad \uparrow \quad$ (dipersepsikan oleh)

Citra Konsumen $\leftrightarrow$ Citra Komunitas $\leftrightarrow$ Citra Investor $\leftrightarrow$ Citra Karyawan

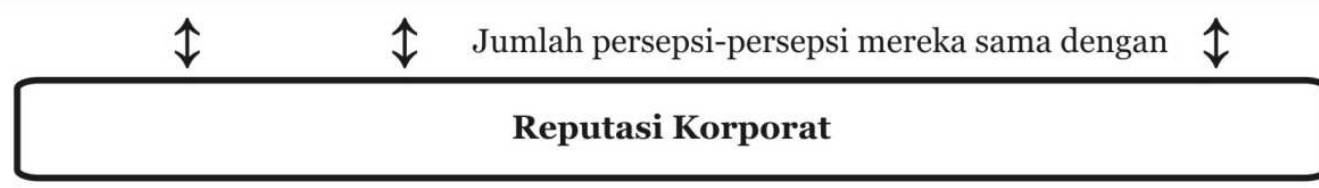

Gambar 1. Kerangka Kerja Reputasi (Argenti, 2010: 96)

Sementara itu, untuk mengatur strategi komunikasi korporat yang efektif, menurut Argenti (2010) meliputi tiga hal yakni menentukan tujuan-tujuan bagi komunikasi tertentu, memutuskan sumber daya apa yang tersedia untuk mencapai tujuan tersebut, dan mendiagnosis reputasi perusahaan. Dalam menerapkan sebuah strategi, sebuah korporat perlu memahami posisi dirinya dalam masyarakat. Hubungan dengan masyarakat merupakan faktor penting dalam proses perubahan organisasi. Sementara Cutlip (2005) berpendapat, ada empat langkah bagaimana organisasi harus bekerja dalam hubungan dengan masyarakat yakni proses pemecahan masalah, mendefinisikan masalah, membuat rencana dan program, bertindak dan berkomunikasi, serta mengevaluasi program.

\section{Komunikasi Korporat KompasTV}

Dalam kasus ini, penulis menggunakan pemikiran Scott M. Cutlip untuk melakukan analisis strategi komunikasi korporat KompasTV sebagai penyedia konten. Strategi korporat berhubungan dengan proses perencanaan strategis hubungan masyarakat yang ditinjau dari sisi internal dan ekternal. 
Ada empat langkah yaitu mendefinisikan masalah, membuat rencana dan program, bertindak dan berkomunikasi, dan mengevaluasi program.

\section{Definisi Masalah}

PT. Kompas Media Nusantara sebagai salah perusahaan media cetak terbesar di Indonesia pun akhirnya terkena dampak globalisasi dan kehadiran new media. Perkembangan teknologi yang semakin cepat dan fenomena media shake-up seperti yang terjadi di Amerika akhirnya menjadi pemikiran sendiri bagi perusahaan untuk kelangsungan hidup media cetak yang mereka miliki. PT Kompas Media Nusantara memiliki surat kabar Kompas yang hingga sekarang masih berada dalam rating teratas surat kabar nasional Indonesia.

Berdasarkan pernyataan Philip Meyer (dalam Sularto 2011), media cetak awalnya akan terancam sejak tahun 2005 dan diperkirakan mati pada 2042 mendatang akibat perkembanga teknologi. Tak hanya soal kelangsungan hidup media cetak, perkembangan teknologi juga memunculkan sebuah era baru yakni era digitalisasi. Era digitalisasi menandakan bahwa berbagai macam teknologi hadir dengan cepatnya. Konvergensi media baik cetak, elektronik, ataupun digital pun terjadi dalam rangka pemenuhan kebutuhan masyarakat akan informasi. Segala materi baik lewat teks, gambar, grafik, video, animasi, dan audio semua tersedia dengan mudah tanpa ada batasnya.

Era digitalisasi sendiri akan serempak dilakukan di Indonesia pada 2018 mendatang dengan penerapan alat telekomunikasi digital seperti televisi serta radio digital. Era televisi digital merupakan hasil konsensus bersama negara-negara dunia yang tergabung dalam International Telecommunication Union (ITU). Era televisi digital, perlu dilakukan di Indonesia mengingat tuntutan penggunaan frekuensi makin besar dengan alokasi terbatas. Dengan era televisi analog seperti saat ini, justru tidak memungkinkan peluang pada masyarakat untuk mendirikan televisi. Hal ini berbeda dengan era televisi digital, dimana peluang mendirikan televisi justru terbuka lebar. Keunggulan lain televisi digital adalah masyarakat lebih disodorkan pada keragaman informasi dan penerimaan gambar yang jernih.

Ketua Komisi Penyiaran Indonesia Daerah (KPID) Yogyakarta, Rahmat M. Arifin, berpandangan ada dua aktor besar yakni network provider dan penyedia konten,

"Network provider ini akan dapat menampung sekitar 6-8 stasiun televisi yang menjadi penyedia kontennya. Ini lebih efisien ketimbang satu televisi harus memiliki pemancar sendiri seperti TV analog saat ini," (Rahmat Arifin, dalam wawancara tanggal 11 September 2011). 
PT Kompas Media Nusantara tampaknya melihat perubahan zaman ini. Kehadiran new media justru menjadi peluang untuk meningkatkan profesionalitasnya sebagai institusi media yang memberikan informasi pada masyarakat. Menurut Sularto (2011: 274), perkembangan teknologi informasi dan terciptanya masyarakat informasi, mendorong Kompas untuk melakukan revolusi. Oleh karena itu, sejak tahun 2010, sesuai dengan tema korporatnya yaitu Membawa Kompas Gramedia ke Dunia Digital", akhirnya Kompas menerapkan strategi $3 \mathrm{M}$ yakni multimedia, multichannel, multiplatform.

$$
\text { Hadirnya KompasTV pada }
$$

September 2011 menjadi bukti bahwa PT Kompas Media Nusantara mengikuti trend new media dan dampak globalisasi. Sebelum ini, Kompas belum memiliki platform sebagai content delivery channel yakni televisi. Dahulu memang Kompas pernah memiliki stasiun televisi yakni $T V_{7}$, namun akhirnya $T V_{7}$ bergabung dengan TransCorp dan berubah nama menjadi Trans7. Dengan hadirnya KompasTV, PT Kompas Media Nusantara ingin menunjukkan bahwa publik dapat mengakses konten Kompas melalui segala wahana (kertas, komputer, televisi, mobile, phone, dan lain-lain). Bentuk konten yang disajikan pun tidak hanya berupa teks dan foto melainkan bentuk grafis, video, atau gabungan semuanya.

$$
\text { Perkembangan teknologi }
$$

membawa keuntungan bagi sebuah

korporat. Hubungan simbiolisis antar multimedia, multichannel, multiplatform semakin memaksimalkan kinerja dan menjangkau khalayak yang lebih luas tanpa dibatasi jarak geografis. Informasi tidak lagi hanya diperoleh dari surat kabar, melainkan dari televisi atau muncul adanya diversity of content. Pilihan yang beragam inilah semakin mempermudah masyarakat untuk melakukan pilihan. Kita ketahui bahwa Indonesia tengah berada dalam masyarakat informasi.

Terlebih lagi televisi memang lebih disukai ketimbang media koran, majalah, atau radio. Televisi merupakan media audio-visual yang memotret peristiwa secara hidup dan menyentuh semua mata sekaligus telinga. Televisi sebagai media massa jauh lebih impresif dan menarik ketimbang media lain karena televisi mampu menampilkan gambar-gambar menarik dan suara. Kekuatan inilah yang menyebabkan televisi sebagai media massa mampu melaksanakan fungsinya lebih optimal seperti mendidik, menghibur, memberikan informasi, hingga pengawasan.

Jacob Oetama (seperti dikutip oleh Sularto, 2011: 413) menyebutkan bahwa menjelang berakhirnya abad XX, akan terbentuk manusia dan masyarakat baru Indonesia. Menurutnya, masyarakat baru Indonesia memiliki tiga ciri utama yakni (1) manusia sadar iptek ketika manusia mampu mencerna informasi yang membanjir dari perkembangan teknologi dan mampu menganilisis atas 
segala perubahan; (2) manusia kreatif dimana manusia memiliki kemandirian dan keberanian untuk mengembangkan kreativitas; (3) manusia beretikasolidaristis dimana manusia lebih peka terhadap keadilan dan solidaritas sosial, menghomati hak orang lain, tenggang rasa, serta menghargai diri sendiri dan orang lain.

Melihat dari pernyataan Jacob Oetama sebagai komisaris utama perusahaan, PT Kompas Media Nusantara sudah melakukan prediksi tentang era digitalisasi sekaligus masyarakat informasi yang akan terjadi di Indonesia ini. Oleh sebab itu KompasTV sebagai platform baru mengusung visi misi yakni mengemas program tayangan news, adventure \& knowledge, entertainment yang mengedepankan kualitas. Konten program tayangan KompasTV menekankan pada eksplorasi Indonesia baik kekayaan alam, khasanah budaya, Indonesia kini, hingga talenta berprestasi.

KompasTV memiliki kecenderungan ingin menyajikan konten yang berbeda dengan media lain. Saat ini, konten televisi nasional lebih mengarah pada acara-acara yang disukai pasar. Terobosan baru yakni dengan mengangkat budaya-budaya Indonesia menunjukkan bahwa PT Kompas Media Nusantara ingin mencoba mengusung idealisme-nya untuk membangun masyarakat Indonesia yang berkualitas. PT Kompas Media Nusantara ingin menunjukkan bahwa pasar bukanlah segala-galanya.
Sementara itu, untuk merealisasikan tujuan PT Kompas Media Nusantara ke dunia digital, diperlukan pula anggaran serta sumber daya manusia. Data mengenai anggaran bersifat rahasia sehingga tidak bisa ditampilkan dalam tulisan ini. Sedangkan untuk manajemen sumber daya manusia KompasTV mempersiapkan Sumber Daya Manusia (SDM) dengan matang. Lungguh Ginanjar, anggota tim produksi KompasTV mengatakan bahwa karyawan baru di KompasTV akan diberi pelatihan dan dibekali kemampuan khusus (wawancara 20 September 2011).

2. Membuat Rencana dan Tujuan Program

Rencana dan tujuan program sangat berhubungan dengan erat tujuan organisasi. Tak hanya itu saja, konstituen pun sangat berpengaruh pada produk yang akan dikeluarkan oleh perusahaan. Konstituen sangat menentukan mati tidaknya sebuah perusahaan, dengan demikian identifikasi kebutuhan, respon, geografis, demografis, psikografis, hingga behavioristik penting dilakukan.

Sebagai sebuah institusi media massa, PT Kompas Media Nusantara berada di antara aktor-aktor yang saling terkait satu sama lain. Aktor ini meliputi pemangku kepentingan, pemerintah, komunitas, pekerja, pelanggan, dan lainnya. Sebagai sebuah perusahaan media yang sudah mendapat reputasi 
yang baik di mata masyarakat, tentunya Kompas sudah melakukan pemetaan terhadap konstituennya.

Jati diri baru yang akan dibangun oleh PT Kompas Media Nusantara lewat KompasTV, tentu saja akan bersentuhan dengan konstituen-konstituen yang baru pula. Misalnya saja, Komisi Penyiaran Indonesia, UU Penyiaran, dan segala hal yang berhubungan dengan dunia penyiaran, yang dahulu tidak bersinggungan langsung ketika mereka menjalankan media cetak (Kompas) dan media internet (Kompas.com).

Sementara itu, ketika melihat program KompasTV, sesuai visi misinya, KompasTV memberikan program news, adventure \& knowledge, entertainment. Program-program ini antara lain news (Kompas,100, Berkas Kompas, Kompas Pagi, Kompas Siang, dll), entertainment (180 Derajat, Kampung Main, Science is Fun, Bumi Kita, Tanah Air, dan lain-lain), dan adventure (Explore Indonesia, Ekpedisi Cincin Api, Jejak Nusantara, Teroka, Weekend Yuk, dan lain-lain).

Bila dilihat dari program yang disuguhkan oleh KompasTV, KompasTV benar-benar ingin memberikan alternatif program yang berbeda dengan media televisi lainnya. Program didominasi oleh content mendidik, lebih variatif disertai dengan penyajian yang menarik dan gaya bercerita feature. KompasTV mencoba menyuguhkan program yaang benarbenar berasal dari anak negeri, baik budayanya, alam, kehidupan sosial, dan lainnya. Hal ini jelas menjadi keunggulan sendiri di tengah gencarnya peranan asing ke pasar dalam negeri.

Tujuan KompasTV untuk menyajikan konten yang berkualitas dan mendidik menjadi bukti bahwa sebagai institusi media, ia melihat bahwa fungsi komunikasi massa saat ini jauh dari yang diharapkan. Menurut Bungin (2011: 332), media massa saat ini justru miskin dari fungsi edukasi nilai-nilai kemanusiaan, media massa justru lebih banyak menjadi corong provokasi nilai-nilai kehewanan, seperti materialistis, hedonisme, seks, konsumerisme, kekerasan, sekularisme, mistisme, dan semacamnya yang menurut banyak kalangan sebagai sumber pemicu berbagai persoalan di masyarakat saat ini.

Terbukti bahwa media massa saat ini banyak menampilkan acara-acara hiburan yang lebih disukai masyarat seperti tayangan mistik dan tahayul, pelecehan seksual, pornografi, kekerasan, dan lainnya. Berdasarkan historologi pornomedia, pornomedia merupakan kecenderungan media massa dalam pemberitaannya: (1) ketika media telah kehilangan idealisme; (2) ketika media merasa tirasnya terancam menurun; (3) ketika media massa perlu bersaing dengan sesama media; (4) ketika media baru memposisikan dirinya di masyarakat; (5) ketika masyarakat membutuhkan pornomedia (Bungin, 2011: 344). 
Lebih lanjut lagi, bila dilihat dari jenis programnya, publik sasaran KompasTV terdiri dari seluruh segmen masyarakat, baik anak-anak hingga dewasa serta laki-laki dan perempuan. Hal ini menunjukkan bahwa fungsi media massa sebagai media edukasi seluruh kalangan benar-benar dijunjung oleh KompasTV di tengah carut marutnya program televisi saat ini. Sementara itu, content program KompasTV ini tidak hanya berdasarkan proses peliputan semata, melainkan menggunakan konten - konten lama dari media cetaknya (Kompas). Sularto (2011: 275) mengatakan,

Penyedia konten Kompas adalah dengan mengembangkan program - program yang mengemas kembali konten - konten lama (bahan teks) ke dalam bentuk yang lebih visual, bergerak, dan menarik. Dengan demikian arsip Kompas dapat kembali dinikmati oleh audiens, terutama audiens muda.

\section{Bertindak dan Berkomunikasi}

Membentuk identitas perusahaan menjadi langkah pertama PT Kompas Media Nusantara untuk memperkenalkan media barunya KompasTV. Setelah media cetaknya memperkenalkan wajah dan format baru pada 28 Juni 2005 lalu, PT Kompas Media Nusantara mulai bergeser wajah ke dunia digital, demi menjawab tuntutan teknologi informasi.
KompasTV hadir dengan taglinenya "Kompas Inspirasi Indonesia" dengan gambar logonya yang terdiri dari berbagai paduan warna. Ini menjadi bentuk identitas perusahaan PT Kompas Media Nusantara untuk melakukan pemasaran produknya. Dengan logo dan tagline tersebut, publik sasaran akan mengetahui siapa produsen barang atau jasa yang akan mereka beli. Meski umur KompasTV masih empat bulan, namun dengan logo dan tagline yang mereka usung, sangat membantu perusahaan untuk memperkenalkan produk barunya.

Tagline sangat berhubungan dengan produk yang akan dijual. Begitu pula dengan KompasTV, yang sesuai visi misinya ingin menjadi media yang menyajikan konten tayangan televisi inspiratif dan menghibur untuk keluarga Indonesia. Bila merujuk pada tagline, visi misi ini, KompasTV sudah menghasilkan produk yang diinginkan. Melalui program acara tayangan news, adventure \& knowledge, entertainment yang menekankan ekplorasi Indonesia (kekayaan alam, khasanah budaya, talenta berpretasi), KompasTV sudah berhasil memberi alternatif program yang berbeda.

Bahkan, untuk membuktikan taglinenya sebagai Inspirasi Indonesia, KompasTV tak hanya berhenti pada program tayangan televisi. Tersedia pula produksi film layar lebar dengan jalan cerita menarik dengan didukung talenta seni berbakat Indonesia. Beberapa film layar lebar yang diproduksi adalah Lima 
Elang dan Garuda Di Dadaku 2 karya Rudi Soedjarwo, serta sebuah film animasi berjudul Si Geboy.

Dengan produksi film karya anak negeri, PT Kompas Media Nusantara ingin menunjukkan bahwa negeri Indonesia memiliki banyak potensi yang bisa dikembangkan. Produksi film anak negeri ini bisa memunculkan generasi-generasi kreatif yang siap berkompetisi di masa depan.

\section{Setelah KompasTV memiliki} identitas perusahaan berupa visual (sesuatu yang bisa dilihat), lalu kita akan melihat bagaimana ia mengkomunikasikan produknya. Untuk mengkomunikasikan produk barunya, KompasTV menamakan dirinya sebagai content provider (penyedia konten). Penyedia konten Kompas menyediakan konten - konten Kompas dalam bentuk program televisi dan film. Tak hanya konten lokal, konten internasional pun juga turut diperhatikan.

Kerja sama dengan 9 televisi lokal di Indonesia adalah bukti cara KompasTV memasarkan produk barunya. Sembilan televisi lokal ini adalah Jakarta, Bandung, Surabaya, Semarang, Malang, Palembang, Pontianak, Makassar, dan Denpasar. Dengan kerja sama operasi dan manajemen, KompasTV memasok program tayangan hiburan dan berita pada stasiun televisi lokal di berbagai kota di Indonesia yang telah terlibat dalam proses kerja sama. Stasiun televisi lokal menayangkan $70 \%$ program tayangan produksi KompasTV dan 30\% program tayangan lokal. Dengan demikian, stasiun televisi lokal memiliki kualitas yang tidak kalah dengan stasiun televisi nasional, tentunya dengan keunggulan kearifan lokal daerah masing-masing. (KompasTV)

Bahkan tak hanya menggandeng 9 televisi lokal semata, KompasTV juga menyediakan kanal televisi berbayar pertama di Indonesia yang memiliki kualitas High Definition (HD). Kualitas High Definition menyajikan gambar dengan resolusi tinggi sehingga pemirsa dapat menikmati detail gambar dengan kontur jelas dan warna yang lebih tajam. KompasTV sebagai pionir kualitas High Definition juga tengah mengarah pada sistem televisi digital sesuai standar yang lazim digunakan secara internasional.

Sementara itu, terkait dengan identitas perusahaan ketiga yakni behavior, penulis tidak bisa melakukan analisis karena belum melakukan observasi langsung dengan objek penelitiannya.

Dalam memasarkan produk sebagai penyedia konten pertama di Indonesia, KompasTV memiliki target baik secara internal maupun eksternal. Target internal berhubungan dengan program jangka panjang yang akan dilakukan KompasTV baik terkait manajemen sumber daya manusia, program, anggaran, publik sasaran, komunikasi internal, dan sebagainya. 
Sedangkan untuk target eksternal berhubungan dengan strategi yang dilakukan perusahaan untuk memasarkan produknya agar diterima di mata konstituennya.

Dalam kasus KompasTV sebagai sebuah unit perusahaan baru, KompasTV masih dalam tahap membangun image (citra). Citra menurut Ardianto (2011: 62) berhubungan dengan perasaan, gambaran diri publik terhadap perusahaan, organisasi atau lembaga; kesan yang dengan sengaja diciptakan agar bernilai positif.

Untuk membangun citra, terlihat jelas bagaimana KompasTV dengan memilih kelompok masyarakat yang mempunyai peranan penting terhadap usaha keberhasilan bisnis. Hal ini terbukti bahwa 9 televisi lokal yang digandeng KompasTV adalah stasiun televisi lokal yang memiliki nama di masing-masing daerahnya. Citra pun dipasarkan di mata karyawannya untuk meningkatkan kinerja dan loyalitas karyawan.

Hal ini juga diakui salah satu penonton setianya, Andreas Tri Pamungkas (25) bahwa KompasTV adalah televisi alternatif yang mendidik dan berkualitas diakui oleh Andreas (25) yang menjadi penonton setianya. Menurutnya, programnya sangat menjunjung tinggi nilai-nilai lokal daerah. Ekplorasi budaya dan alam, justru menjadi program penting yang belum menjadi perhatian stasiun televisi lainnya.
"KompasTV berbeda dengan TV lain. Kontennya sangat bermutu dan mendidik. Penjelasan materi pun tampak komprehensif, indepth informasi, dan menarik. Sedangkan TV lain lebih pada program acara yang mengikuti selera pasar seperti sintron, takhayul, dan lainnya." (Andreas, dalam wawancara 18 September 2011)

Saat ini, KompasTV tengah membangun citranya sebagai televisi Inspirasi Indonesia dan penyedia konten berkualitas. Meski ia adalah bagian dari PT Kompas Media Nusantara atau Grup Kompas Gramedia yang kita ketahui sudah memiliki reputasi yang baik, namun reputasi KompasTV tidak bisa muncul begitu saja. Baru menginjak usia empat bulan sebagai televisi penyedia konten, bukan hal yang mudah untuk mendapatkan reputasi. Lebih lagi tayangan KompasTV masih terbatas di 9 televisi lokal dan televisi berbayar. Dengan demikian, dapat terlihat bahwa publiknya pun belum menjangkau seluruh masyarakat Indonesia.

Reputasi memiliki sejumlah elemen penting yakni para pemegang saham, karyawan, dan pelanggan. Ardianto (2011: 73-74) mengatakan reputasi juga diciptakan melalui interaksi betingkat melalui hasil jaringan dari semua pengalaman, kesan, kepercayaan, perasaan, dan pengetahuan yang dimiliki orang mengenai sebuah perusahaan.Reputasi dapat diukur dan 
Olivia Lewi Pramesti, Pembentukan Identitas Korporat PT Kompas Media Nusantara sebagai Penyedia Konten (Content Provider) Televisi Lokal Pertama di Indonesia

perusahaan cenderung membuat instrumen untuk mengukurnya.

\section{Evaluasi Program}

Berkaitan dengan evaluasi program ini, KompasTV memang menampilkan program yang berbeda dengan industri televisi saat ini. Di tengah masyarakat haus hiburan dan industri media mengejar rating, KompasTV tetap memiliki independensi untuk mengusung konten yang berkualitas.

Meski visi dan misi KompasTV bagus, artinya dari program dan kontennya yang berkualitas, namun KompasTV tengah berurusan dengan krisis. KompasTV dihadapkan pada persoalan regulasi televisi digital dan bisnis media di Indonesia yang saat ini tengah disusun oleh pemerintah. Artinya bahwa, KompasTV lebih awal mencuri start untuk masuk ke era digitalisasi tersebut. Lebih lagi menyebut dirinya sebagai penyedia konten di bagi televisi lokal di Indonesia. Hal inilah yang memicu kontroversi dari berbagai pihak tentang kehadiran KompasTV.

Ketua Komisi Penyiaran Indonesia Daerah (KPID) Yogyakarta, Rahmat Arifin, mengatakan saat ini Indonesia masih dalam tahap sosialisasi televisi digital. Tahap sosialisasi dimulai dari tahun 2008 hingga 2012, tahap uji coba di 10 kota besar dan daerah terpilih dari tahun 2013 hingga 2017, dan tahap televisi digital pada tahun 2018 mendatang.
"Regulasi tentang TV digital baru akan muncul setelah proses sosialisasi dan uji coba selesai. Dalam tahap uji coba, semua TV di Indonesia harus melakukan siaran secara simulkas atau bersiaran secara analog dan digital dalam waktu bersamaan. Setelah itu, regulasi bagi pemilik media untuk mendirikan TV lokal di daerah dipersilahkan.” (Arifin, dalam wawancara 11 September 2011)

Kemunculan televisi menuai beberapa protes dari berbagai pihak karena masalah penggunaan kata "TV" dan kebijakan KompasTV menggandeng 9 televisi lokal di Indonesia. KompasTV dinilai institusi yang tak berizin. Akhirnya, Pemimpin Redaksi KompasTV Taufik Hidayat Mihardja mengklarafikasi hal ini dengan mengatakan bahwa KompasTV adalah penyedia konten, bukan penyelenggara siaran, jadi tak perlu punya izin siaran.

Kebijakan KompasTV untuk menggandeng televisi lokal pun dinilai bermasalah. Meski hanya sebagai penyedia konten bagi televisi lokal namun tetap membutuhkan ijin siaran. Menurut Menteri Komunikasi dan Informatika (Menkominfo) Tifatul Sembiring, ada aturan untuk menyiarkan program di televisi lokal yang belum memiliki Izin Prinsip Penyiaran (IPP). KompasTV yang bekerja sama dengan 9 televisi lokal, baru dua saja yang sudah mendapatkan IPP yaitu di Kalimantan Selatan dan Sumatera Utara. 
Belum adanya regulasi yang mengatur kebijakan digitalisasi di Indonesia tentu saja kan menyulitkan KompasTV untuk menambah pasarnya. Hal ini tidak bisa dihindari oleh sebuah perusahaan karena dia berada dalam sistem politik. Mau tak mau, KompasTV harus menunggu peraturan tersebut untuk tujuan meluaskan pasarnya. Seperti dikatakan oleh Rahmat M. Arifin, S.Si sebagai berikut.

"Pemilik media belum bisa mendirikan TV lokal di daerah. Mereka harus tetap patuh pada peraturan. Proses sosialisasi harus dituntaskan terlebih dahulu, supaya masyarakat siap memasuki era digitalisasi ini. "(Arifin, dalam wawancara 11 September 2011)

\section{Penutup}

Sebagai brand baru, KompasTV memiliki tagline Kompas Inspirasi Indonesia dengan menyebut diri sebagai penyedia konten. Perlu diketahui penyedia konten ini merupakan fenomena pertama di Indonesia. Dengan mengusung tagline tersebut, KompasTV ingin menunjukkan bahwa dia bukanlah televisi seperti kebanyakan, namun televisi yang benarbenar menyajikan konten berkualitas. Oleh karena itu, KompasTV konsen pada program-program yang mengangkat negeri Indonesia seperti budaya, alam, serta prestasi anak negeri.

Kehadiran KompasTV memang membawa keuntungan bagi perusahaan. Selain mendatangkan profit bagi perusahaan, tujuan institusi media yakni menyebarkan informasi masyarakat bisa terealisir, bahkan dengan jangkauan yang lebih luas. Lewat KompasTV, konten Kompas dalam bentuk cetak dan internet bisa dinikmati dalam wahana apapun. Informasi yang diberikan pun akhirnya tidak terbatas pada satu media melainkan beragam.

Tak hanya soal profit, efisiensi biaya, tenaga waktu, fasilitas, dan sebagainya bisa terwujud dengan adanya KompasTV. Media baru dengan cirinya yakni digital, memungkinkan perusahaan untuk meningkatkan produktivitas dan daya saingnya.

Dalam membangun image barunya sebagai televisi penyedia konten, bukan persoalan yang mudah bagi KompasTV. KompasTV masih terkendala dengan jangkauan pasar serta regulasi dari pemerintah. Tak hanya itu, masyarakat Indonesia pun belum banyak memahami tentang era digitalisasi media. Era digitalisasi media membutuhkan proses transisi kultural yang tidak bisa secara langsung.

Berbicara tentang komunikasi korporat dan strateginya, khususnya sebuah perusahaan baru yang ingin membentuk corporate image di mata masyarakat seringkali dihadapkan pada perencanaan yang belum matang. Perencanaan ini bisa terkait dengan dengan identitas korporat, manajemen sumber daya manusia, anggaran, tujuan, 

sebagai Penyedia Konten (Content Provider) Televisi Lokal Pertama di Indonesia

produk yang akan dipasarkan, hubungan dengan konstituen, dan lain sebagainya.

Ini berkaitan dengan identitas korporat. Identitas korporat adalah jati diri perusahaan. Kecenderungan yang terjadi saat ini, identitas korporat hanya dilihat semata-mata hanya dari aspek visual, seperti logo, warna, nama organisasi, huruf. Padahal, identitas korporat juga ditunjukkan lewat sesuatu yang tidak tampak seperti bagaimana perusahaan mengkomunikasikan produknya (kaitannya dengan pesan, media yang digunakan), serta perilaku dari pihak internal. Ketiga hal ini menjadi hal pokok dalam pembentukan corporate identity yang akhirnya memengaruhi corporate image dan membentuk reputasi perusahaan.

Kaitannya dengan masalah masalah behaviour, memang terkadang terkendala dalam proses kontrolnya. Kendati begitu, aspek ini selalu memperhitungkan tiga hal yakni perubahan sikap pribadi (etika pribadi), sistem yang diubah, serta kondisi sosial masyarakat.

Sementara itu, berhubungan dengan reputasi perusahaan yang dapat diukur, seringkali sangat berhubungan dengan history dan power. Meskipun reputasi sebuah perusahaan jelek, namun ketika dilihat dari sisi history-nya yang kuat serta power yang dimilikinya, maka reputasi yang awalnya jelek justru bisa positif. History dan power sangat berpengaruh terhadap reputasi sebuah perusahaan. Bahkan dua aspek ini ketika dihubungkan dengan reputasi perusahaan sangat berpengaruh dibanding logo, nama perusahaan, dan lainnya. History dan power sangat berpengaruh pada stakeholder atau konstituen-konstituen di sekeliling organisasi.

Perencanaan lain terkait strategi korporat adalah berhubungan dengan sumber daya manusia. Banyak fenomena yang terjadi di lapangan, karyawan baru dibiarkan begitu saja untuk melaksanakan pekerjaan sesuai tujuan perusahaan. Tentu saja hal ini membuat tidak maksimalnya tujuan perusahaan. Karyawan perlu diberi pelatihan terlebih dulu agar budaya perusahaan juga masuk dalam dirinya. Membuat karyawan menjadi loyal terhadap perusahaan tentu saja menjadi catatan bagi perusahaan untuk makin meningkatkan daya saingnya.

\section{Daftar Pustaka}

Ambardi, Kuskrido. 2011. "Kocok-Ulang Bisnis Media: Dilema Strategi Kebijakan Digital di Indonesia". Paper, disajikan dalam Seminar Nasional Media Baru : Studi Teoritis dan Telaah dari Perspektif Politik dan Sosiokultural. Jurusan Ilmu Komunikasi, FISIPOL, Universitas Gadjah Mada, Yogyakarta 14 Desember 2011. 
Ardianto, Elvinaro. 2011. Handbook of Public Relations. Bandung: Simbiosa Rekatama Media.

Argenti, P. 2010. Komunikasi Korporat, Vol.5 (S, Putri Aila Idris, Penj.). Jakarta: Salemba Humanika.

Bungin, Burhan. 2011. Sosiologi Komunikasi: Teori, Paradigma, dan Diskursus Teknologi Komunikasi di Masyarakat. Jakarta: Prenada Media Group.

Croteau, David and William Hoynes. 2001. The Business of Media, Corporate Media and The Public Interest. California: Sage Publications.

Cutlip, Scott M., Allen H. Center, dan Glen M. Broom. 2005. Effective Public Relations, Vol.8 (S.S, Pohan, Ch. Renata V.H, Penj.). Jakarta: PT Tunas Jaya Lestari..
Sularto, ST. 2011. Syukur Tiada Akhir, Jejak Langkah Jokob Oetama. Jakarta: PT Kompas Media Nusantara. . “2018, Indonesia Mulai Era Televisi Digital”. http://nationalgeographic.co.id/liha t/berita/2597/2018-indonesiamulai-era-televisi-digital, diakses 13 Januari 2013.

"Ini Penjelasan Menkominfo Soal KompasTV'.

http://news.okezone.com/read/201 1/o9/10/339/500993/inipenjelasan-menkominfo-soal kompas-tv. Diakses 10 September 2011.

“KompasTV Hanya Penyedia Konten”. http://nasional.kompas.com/read/2 011/o9/o9/15564158/Kompas.TV.H anya.Content.Provider. Diakses 9 September 2011 